\title{
Mangandung dalam Perkabungan Masyarakat Batak Toba
}

\author{
Rosmegawaty Tindaon ${ }^{1}$, G.R. Lono Lastono Simatupang, Victor Ganap, \\ dan Timbul Haryono
}

Program Studi Pengkajian Seni Pertunjukan dan Seni Rupa, Universitas Gadjah Mada, Yogyakarta

\begin{abstract}
ABSTRAK
Menurut kepercayaan masyarakat Batak Toba kematian bukan sebuah totalitas tetapi sebuah perpisahan parsial. Ada kepercayaan bahwa kematian tidak pernah memisahkan manusia secara total, hal ini terungkap lewat ritual yang dilakukan saat anggota keluarga meninggal, konteks kematian dalam masyarakat Batak Toba adalah adat istiadat mereka. Salah satu ritual adat kematian adalah kebiasaan mangandungi jenazah. Mangandung adalah salah satu ritual kematian yang berasal dari kata andung yang artinya ratap. Kebiasaan mangandungi pada masyarakat Batak Toba berkembang menjadi kesenian yang dikenal dengan tradisi nyanyian andung. Tradisi mangandung dianggap sebagai bagian dari adat dan tergolong penting sebagai bentuk ekspresi kesedihan dengan kata kata dan irama tertentu. Penelitian ini menggunakan metode etnografi.

Kata kunci: Batak Toba, upacara kematian, Andung-andung
\end{abstract}

\begin{abstract}
Mangandung in a Mourning Ritual of Batak Toba Society. According to a belief of Batak Toba society death is not a totality but a partial separation. There is a belief that death never separates human totally. It is revealed through the ritual performed when family members died in which the context of death in Batak Toba society is their custom. One of the customary rituals of death is the habit of mangandungi of the bodies. Mangandung is one of the rituals of death that comes from the word andung which means lamentation. The habit of mangandungi in Batak Toba society develops into an art known as the andung singing tradition. Mangandung tradition is considered as a part of a custom and is important as a form of expression of sadness with certain words and rhythms. This research used ethnography method.
\end{abstract}

Keywords: Batak Toba, funeral, Andung-andung

\section{Pendahuluan}

Kematian adalah salah satu tahap keniscayaan kodrati dalam proses kehidupan manusia. Sebagai sebuah keniscayaan, tahap ini tidak bisa dihindari oleh siapa pun. Dengan kata lain, peristiwa kematian akan mendatangi setiap manusia. Maka, tidak salah jika setiap masyarakat memiliki pandangan yang unik tentang peristiwa ini. Pandangan mereka tentunya dipengaruhi oleh cara pandang mereka tentang manusia, dari mana manusia dan kemana manusia setelah mati. Dengan demikian, agar bisa memahami cara pandangan masyarakat tentang kematian, yang perlu dipahami terlebih dahulu adalah cara pandang tentang manusia itu sendiri. Menurut masyarakat Batak Toba, manusia adalah subjek yang utuh karena tiga komponen penting: tondi, roha, dan pamatang (Nainggolan 2012: 24). Manusia memiliki tujuan untuk menggapai hamoraon, hagabeon dan hasangapon. Ketiga tujuan hidup ini menjadi impian bagi setiap orang. Sementara itu, mereka juga percaya bahwa kehidupan akan berakhir pada kematian. Namun, kematian tidak pernah memisahkan mereka dari keluarga dan juga relasi mereka dengan Debata mula jadi nabolon.

1 Alamat korespondensi: Prodi PSPR, Sekolah Pascasarjana Universitas Gadjah Mada, Jln. Teknika Utara, Pogung, Sleman, Yogyakarta - 55281. E-mail: rosmegawatytindaon@gmail.com. 
Masyarakat Batak Toba memiliki pandangan yang cukup unik tentang kematian. Kematian tidak akan pernah memisahkan mereka dari relasi keluarganya. Itulah mengapa dalam adat istiadat Batak Toba, relasi terhadap nenek moyang tetap mereka jaga karena mereka sangat yakin bahwa ketika orang meninggal, yang mati adalah badannya. Tondi mereka tetap hidup dan bahkan bisa memiliki derajat yang lebih tinggi jika keturunannya dapat melakukan pesta besar yang disebut panaingkon saring-saring.

Sonni mengemukakan pendapat bahwa: Orang Batak sangat menghormati arwah para leluhur yang telah meninggal dalam usia tua. Semakin tua usia dan semakin banyak keturunannya, maka arwahnya semakin dihormati dan diagungkan. Mereka yakin bahwa arwah dapat memberkati dan menjauhkan keturunannya dari segala macam bahaya. Dengan demikian orang Batak menganggap upacara kematian merupakan suatu upacara yang wajib dilaksanakan demi ketentraman jiawa keturunannya yang sekaligus memenuhi tuntutan adat (Mei Sonni, 2010: 31).

Ada beberapa istilah yang dipakai untuk kata meninggal yang disematkan kepada manusia. Di adat dalihan na tolu, orang meninggal disebut mate. Lebih halus disebut jumolo yang secara harafiah berarti lebih dahulu" Istilah lain adalah monding, singkatan dari modom onding yang berarti tidur tertutup. Orang yang meninggal dianggap tidur namun tertutup di bawah tanah (Richard Sinaga, 2010: 35).

Jenis upacara kematian menurut orang Batak Toba meliputi: tilahaon (upacara kematian anak), mate ponggol (meninggal sebelum menikah), mate diparalangngalangan (meninggal sudah menikah tetapi belum dikaruniai anak), mate mangkar, matipul ulu, dan mantompas tataring (meninggal dengan meninggalkan anak keturunan yang masih kecil), mate hatungganeon (meninggal belum memiliki cucu), mate sari matua (meninggal belum memiliki cucu), Mate saur matua (meninggal sudah mempunyai anak cucu) dan Saur matua bulung (meninggal sudah memiliki cicit dari anak laki laki dan anak perempuan).

Pada upacara kematian di Batak Toba, setiap fasenya memiliki kekhasan yang dikenal oleh masyarakat setempat dengan nama mangandung (meratapi).

\section{Andung}

Andung merupakan salah satu bentuk seni suara dan sastra yang berkembang di masyarakat Batak Toba. Andung adalah ratapan yang dilakukan pada saat upacara ritual kematian. Andung merupakan salah satu ritual adat yang bersifat tradisi yang dilantunkan pada saat ada keluarga atau kerabat yang meninggal dalam bentuk ratapan sebagai ungkapan kesedihan dari pihak keluarga yang ditinggalkan. Ratapan dilantunkan dibarengi dengan kata-kata yang berisikan cerita tentang kebaikan-kebaikan si jenazah atau ungkapan rasa sayang dari keluarga terhadap yang meninggal. Kegiatan melantunkan andung disebut juga dengan istilah mangandung. Andung pada peristiwa kematian merupakan salah satu tahapan yang dilakukan masyarakat Batak Toba pada saat upacara perkabungan. Dalam tatanan kehidupan masyarakat Batak Toba tidak ada aturan tertulis yang mengharuskan melantunkan andung, tetapi ada aturan yang tidak tertulis terkait dengan ritual melantunkan andung dalam upacara perkabungan. Ada semacam keharusan bagi keluarga yang ditinggalkan untuk melantunkan andung. Masyarakat setempat memandang ini sebagai wujud kepedulian dan rasa sayang atau simpati keluarga yang ditinggalkan terhadap si jenazah. Sebagai contoh yang memperlihatkan suatu keharusan melantunkan nyanyian andung yaitu seorang istri apabila tidak melantunkan andung pada saat suaminya telah meninggal akan dianggap tidak peduli atau tidak sayang kepada si jenazah. Hal ini akan memicu reaksi dari keluarga lain dalam bentuk teguran bahkan diperlihatkan dalam bentuk sikap.

Menurut Manna (wawancara, 2016) kemampuan melantunkan andung tidak dipelajari secara tertulis. atau diajarkan secara lisan, malainkan melalui kondisi lingkungan budaya masyarakat Batak Toba, yang menjadikan seseorang bisa melantunkan andung. Diawali pada saat salah satu keluarga atau orang yang terdekatnya meninggal dunia. Mereka merasakan kesedihan yang sangat 
mendalam dan mengucapkan kata-kata tertentu yang mempunyai makna yang berhubungan dengan kebaikan dan penderitaan si jenazah.

Berkaitan dengan batasan usia, Manna menyebutkan bahwa tidak ada batasan usia sejak kapan seseorang bisa melantunkan andung (Manna: 2016:15-7). Ada beberapa kondisi yang berbeda yang mengawali seseorang mulai malantunkan nyanyian andung; antara lain ketika seseorang berusia 9 tahun ditinggal oleh ibunya, tanpa disadari peristiwa itu menjadi awal baginya untuk memiliki kemampuan melantunkan andung (Marisi 2016: 17-7). Selanjutnya (Tiaggur 2016:15-7) mulai melantukan andung pada saat usia 8 tahun pada saat ibunya meninggal, sejak peristiwa itu dia mengandung pada saat keluarganya atau kerabatnya meninggal. Pada kondisi lain, seseorang baru mulai melantunkan andung pada usia dewasa. Pelantun andung memiliki kemampuan melantunkan andung ketika mengalami secara langsung suatu pengalaman disaat anak kandung yang meninggal (Rumona, 2016, 16-9). Artinya, pengalaman melantunkan andung umumnya dimulai ketika si pelantun berada dalam pengalamannya yang menyedihkan karena ditinggal oleh orang yang dekat dengan mereka. Menggunakan istilah Bourdieu (Prasetya, 2010), seseorang bisa menyanyikan andung karena habitus. Mereka bisa melantunkan andung secara belajar walaupun secara tidak disadari. Tindakan mengandung-pun menjadi tindakan yang tidak disadarai.

Andung dalam upacara perkabungan umumnya dilakukan oleh perempuan. Ada kecenderungan melantunkan andung hanya dilakukan oleh keluarga si jenazah (keluarga dekat atau jauh), tetapi sebagai bentuk kepedulian ada juga yang melantunkan andung kepada teman yang tidak ada hubungan keluarga. Dalam banyak kasus, orang melantunkan andung sebagai bentuk kepedulian masyarakat kepada ale-ale (sahabat karib), sebagai tetangga, sebagai dongan sa huta (teman sekampung), atau sebagai orang yang mereka kenal cukup baik keperibadiannya. Akan tetapi, secara umum masyarakat Batak Toba melantunkan andung hanya dilakukan oleh keluarga, mereka tidak melantunkan andung kepada orang lain yang tidak ada hubunngan kekerabatan.
Andung biasanya dilakukan oleh perempuan tetapi tidak ada larangan apabila laki-laki ingin melantunkan andung. Andung dapat dilakukan pada saat jenazah sudah dimakamkan. Tempat melantunkan andung bisa dilakukan di samping jenazah secara langsung atau di tempat lain (tidak harus di samping jenazah). Andung dalam upacara perkabungan boleh dilakukan bersamasama dengan anggota keluarga yang lainnya secara serentak. Tidak ada batasan jumlah orang dalam melantunkan andung (boleh lebih dari satu, dua, tiga, dan empat orang) Andung dilakukan oleh lebih dari satu orang terjadi apa bila kondisi keluarga si jenazah menimbulkan keprihatinan kaum kerabat yang datang melayat. Para pelayat secara pisikologis prihatin atau terharu akan merasa lebih tenang dan lega setelah mangandungi jenazah.

Kata-kata dalam syair andung tidak selalu sama dan memiliki arti yang sama. Syair dalam andung yang telah dilantunkan sebelumnya tidak dapat ditiru atau dicontoh. Kata-kata diucapkan dengan mengalir begitu saja tanpa sebelumnya mempelajari teks atau menghafal syair-syair ter- $/$ tentu. Kata-kata itu murni berdasarkan pada kemanpuan berimprovisasi pelantun andung yang berpatokan dari kondisi yang meninggal, keadaan kondisi keluarga yang ditinggalkan serta ungkapan rasa sayang dari keluarga kepada yang meninggal. Jika ditemui ada kesamaan dalam kata-kata yang diucapkan pada saat melantunkan andung maka itu terjadi begitu saja dan tidak ada unsur kesengajaan.

Pada dasarnya, kata-kata yang dilantunkan selalu sesuai dengan kenyataan atau kisah hidup si jenazah. Namun ada juga kejadian di beberapa tempat bahwa kata-kata yang dilantunkan tidak berkenan di hati keluarga yang mendengarkan. Mungkin karena tidak sesuai dengan keadaan yang sebenarnya. Biasanya pihak keluarga akan menegur (marah) serta menyuruh si pelantun andung berhenti. Bahkan terkadang sampai diusir ke luar dari rumah duka (Marisi dan Tianggur, 2016: 20-9).

Perkataan yang disampaikan pada saat melantunkan andung merupakan ungkapan kesedihan dari keluarga yang ditinggalkan. Makna lain dari kata-kata andung bisa saja merupakan tentang kebaikan yang meninggal pada masa hidupnya atau tentang kewajiban yang meninggal yang belum 
terselesaikan pada masa hidupnya. Tidak jarang andung dipergunakan untuk mengungkapkan suatu perbedaan pendapat yang terjadi dalam keluarga yang meninggal serta sesekali kata-kata yang diucapkan bisa saja tidak sesuai dengan kondisi atau situasi orang yang meninggal semasa hidup (Marisi, 2016: 22-9).

Pada masa lalu andung yang dilakukan oleh masyarakat Batak Toba masih menggunakan katakata yang memiliki nilai sastra dan estetika yang tinggi. Seiring dengan perkembangan, kata-kata yang diucapkan perlahan-lahan tidak memperhatikan nilai sastra dan estetika lagi. Mereka hanya menonjolkan kata-kata biasa, sehingga kalau diamati, andung hanya seperti orang meratapi atau menangisi yang meninggal.

Teks yang diucapkan oleh orang yang melantunkan andung pada upacara perkabungan disaat sekarang diungkapkan dengan kata-kata yang digunakan dalam kehidupan sehari-hari dan sederhana sehingga dengan mudah dipahami oleh yang mendengarkan.

Andung menyampaikan "ungkapan perasaan dukacita” melalui kata-kata yang teratur, indah dan penuh kesedihan atas meninggalnya kerabat tercinta. Andung dalam peristiwa kematian selalu dilantunkan di dekat jenazah orang yang meninggal. Kata-katanya dilantunkan secara spontan tanpa ada persiapan khusus. Kadang dipenuhi dengan kenangan masa lalu, dan juga kepedihan yang mendalam karena pengalaman ditinggalkan. Pada mate mangkar, kepedihan itu akan semakin mendalam karena masih adanya anak-anak kecil yang ditinggalkan oleh mendiang.

Andung merupakan sejenis sastra lisan yang berisi curahan perasaan untuk meratapi jenazah orang yang dikasihi (Nalom Siahaan, 1982: 70). Penggunaan teks yang digunakan kadang berasal dari istilah-istilah kuno dalam bahasa Batak Toba sehingga kadang tidak lazim didengarkan telinga. Ratapan andung termasuk tradisi lisan karena diwariskan secara turun-temurun berupa susunan kata-kata lisan (verbal), mengandung nilai-nilai budaya sebagai kearifan lokal, dan milik bersama komunitas tertentu (Sibarani, 2012: 123).

Ratapan (andung) dalam konteks kematian mempunyai fungsi/tujuan sebagai suatu ekspresi dukacita yang terstruktur/terbentuk dan yang memenuhi kebutuhan adat untuk menghormati/ memperingati orang yang meninggal (serta roh/ tondi orang itu dan tondi nenek moyang yang duluan meninggal) (Hodges, 2006: 8). Hodges menunjukkan bahwa dalam melantunkan andung, pangandung merasakan adanya hubungan yang masing masing bisa dijaga walaupun badan yang meninggal sudah mati. Salah satu komponen manusia, tondi, diyakini sebagai komponen yang masih hidup sehingga masih bisa melakukan hubungan komunikatif lewat andung-andung. Hodges juga menjelaskan bahwa ratapan juga berfungsi sebagai semacam saluran komunikasi antara dunia ini dan dunia lain agar permohonan dari dunia ini diajukan kepada nenek moyang dan tuah/berkat dari mereka dapat diberikan kepada orang yang hidup (Hodges, 2006: 9).

Bagi orang Batak Toba tradisi melantunkan andung dianggap sebagai bagian dari adat dan dimasukkan dalam kategori yang sangat penting. Sihombing menerangkan pentingnya tradisi ini dengan satu pengandaian, "jika seorang anak tidak mau mangandungi orang tuanya yang meninggal maka orang tersebut dianggap "tidak tahu adat" (Sihombing, 1986: 122). Pentingnya tradisi bahkan dikaitkan dengan seberapa dalam seseorang memahami budaya Batak.

Masyarakat Batak Toba memahami peristiwa kematian melalui ritual tertentu yang mereka kenal dengan mangandung. Mereka mungkin menghadapi peristiwa kematian dengan tangisan yang tersedusedu. ketika seorang mangandungi akan keluar air mata karena kesedihan yang dia rasakan. Namun, bagi orang Batak Toba, "mangandungi" berbeda dengan "menangisi". "Menangisi" dipahami sebagai ekspresi kesedihan tanpa mengungkapkan secara langsung apa penyebab kesedihannya dengan katakata dan irama tertentu.

Sejarah munculnya tradisi mangandung tidak ada yang tahu secara pasti. Sihombing (1986:123) menyampaikan cerita yang pernah dia dengarkan dari tua-tua adat:

Pada zaman dahulu ada seorang raja, yang pada waktu itu dia hendak meninggal dunia berpesan kepada keluarganya, 'kalau saya mati, janganlah kalian hanya 
menangisi saya, tetapi dalam menangisi saya itu, ceritakanlah semua perbuatanperbuatanku yang telah membuat hidupku termasyur.

Semenjak itu melantunkan andung orang yang meninggal menjadi adat yang selalu dilakukan sebagai ungkapan dukacita sekaligus menceritakan amal perbuatan orang yang meninggal. Semakin banyak yang turut melantunkan andung orang yang meninggal, maka berarti akan semakin tinggi dan masyhur martabat orang yang telah meninggal tersebut.

Kebiasaan mangandungi orang yang meninggal pada akhirnya menjadi salah satu bentuk kesenian dan sekaligus sebagai identitas dari budaya masyarakat Batak Toba. Mangandung merupakan simbol kasih sayang yang diungkapkan keluarga yang ditinggalkan, dan salah satu bentuk pelestarian budaya daerah untuk memperkuat identitas masyarakat Batak Toba.

Tradisi andung ini masih dilakukan diberbagai daerah baik di tanah Batak Toba, maupun di tanah perantauan. Orang yang melantunkan ratapannya selalu melakukannya secara langsung tanpa ada disuruh, atau direncanakan. Mereka datang dan melihat jenazah. Dari hati mereka muncul rasa sedih dan langsung secara spontan secara personal mereka melantunkan andung. Orang tidak lagi hanya memperhatikan dan menilai kata-katanya saja dalam mengungkapkan perasaan dukacita tetapi juga gerak-gerik dan alunan suara orang yang mangandung.

\section{Tema-tema Syair Andung}

Andung memiliki banyak tema walaupun yang umum didengarkan adalah andung tu na mate (ratapan untuk orang yang meninggal). Tema-tema nyanyian andung pada umumnya semua ekpresi sedih yang dilantunkan dengan kata-kata boleh dikatakan meratap. Dengan kata lain, nyanyian andung memilik cakupan yang cukup luas dalam kaitannya sebagai ekspresi pengalaman seseorang. Sesorang dapat meluapkan perasaaanya melalui ratapan, terlepas dari konten ratapan atau konteks dimana meratap itu dilakukan. (Hodges. 2009: 262).
Berikut salah satu contoh syair andung di daerah Harian Boho Samosir, di lantunkan oleh seorang anak perempuan si Jenazah.

\section{Syair Andung}

Bapa... yamang tahe...

Ndang tarlupahon ahu sude..

Podami tu abu

Bapakku... u...u..u...

Marhua do ro ho ...

lompa paridianhu..nimmu...

Hulompa do... oo..oo.. malojahu ho...

Hu siampudan i...HP mi dilean ho do.

Hu si Anis, ndang leanonmu...

Unang si Anis nimmu do...

Boha do paninggalhonmu di hami sude Bapakku...

(Glendwey: 2016).

Ayah... yamang tahe...

Tidak dapat kulupakan semua nasehat mu,

kepadaku

Ayahku...u..u.. u..

Buat apa engkau datang....

Masak dulu air mandiku, katamu...

kumasaknya... o..o..o..

terlalu capek engkau...

Kepada anak bungsuku...

handphone mu engkau berikan. Kepada si Anis, tidak engkau berikan...

Jangan ke si Anis, katamu....

Bagamana kepergian mu bagi kami semua

Ayahku...

Andung ini adalah ratapan seorang putri atas meninggalnya ayah yang dikasihinya. Dia menyatakan bahwa sang Ayah telah memberikan nasehat-nasehat yang baik kepadanya dan itu sangat berkesan dan tidak dapat dilupakan. Dia sangat dekat dengan ayahnya. Air mandi untuk ayah dia masak karena dia melihat ayahnya terlalu lelah. Dalam ratapannya, dia mengungkapkan bahwa ayahnya sayang kepada cucunya, sehingga anak bungsu dari putrinya diberi hadiah handphone yang tadinya adalah milik sang ayah. Walaupun, cucu yang diberi hadiah adalah anak bungsu bukan kakak dari anak bungsu tersebut. Kenangan-kenangan inilah yang membuat hati 
peraratap bersedih, sehingga dia mengungkapkan kesedihannya dengan bertanya, kenapa begitu tega sang Ayah meninggalkan mereka.

\section{Analisis Musik Andung}

Menganalisis musik dilakukan detail dari awal hingga akhir sebuah lagu dari segi struktur musik (Prier, 1996: 1) Musik yang dikaji dalam penelitian ini adalah andung yang dilantunkan secara spontanitas dan personal tidak menggunakan notasi yang sudah baku seperti notasi angka dan notasi balok. Agar mudah di pahami dan dibaca penulis menggunakan penulisan notasi balok musik yang standar di Indonesia. "...timbul dugaan bahwa unsur melodi menyebabkan "rasa" atau "seni musik" sedangkan ritme" meliputi fungsional (Prier, 1966: 1). Setelah mengamati melodi-melodi yang sudah di tulis akan tampak: (1) Karakter dan peran sangat bervariasi sesuai dengan estetika masing-masing, fungsi, kebutuhan, bahkan aspek individual. (2) Unsur-unsur melodi kadang-kadang sama sekali tidak merupakan pola dasar salah satu jenis musik khususnya pengertian konvensional (Dieter Mack, 1966, 7-8).

Andung ditranskripsikan dengan pendekatan yang dikemukakan oleh Bruno Nettl bahwa pendiskripsian musik ada dua pendekatan yaitu: (1) pendekatan berdasarkan apa yang kita dengarkan lalu dideskripsikan dan menganalisis. (2) pendekatan berdasarkan penglihatan lalu menulis dan mendeskripsikan ( Bruno Netll, 1964: 97). Netll juga mengemukakan pendapat yang di
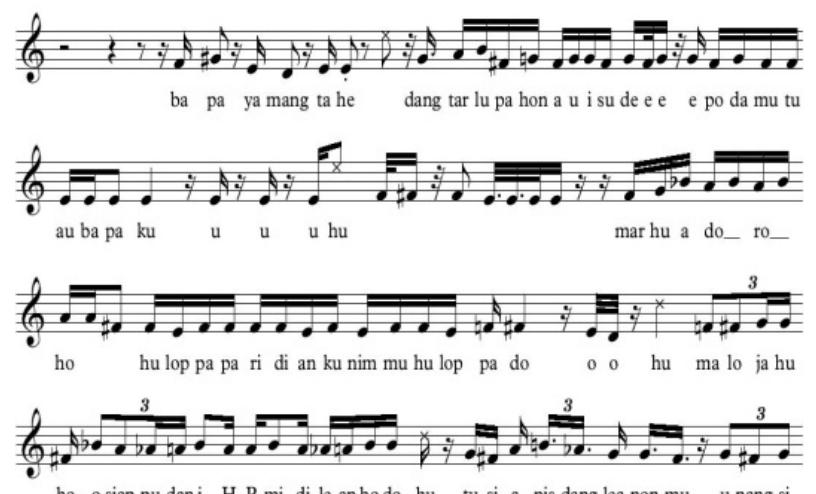

ho, o siap pu dani H P mi di le anhodo hu tu si a nis dang lea non mu u nang si

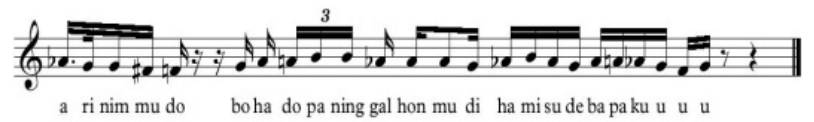

Notasi 1. Notasi andung tulis oleh Charles Seeger, yaitu pendekatan yang dinamakan dengan preskriptif yaitu mengarahkan seorang penyanyi, symbol-simbol notasi preskriftif perangkat mnemonik untuk membantu ingatan dan memperlihatkan sedikit arahan umum untuk pergerakan melodi, dan deskriptif yaitu memberikan informasi kepada pembaca tentang karakteristik-karakteristik dari sebuah komposisi yang belum dikenal orang.

Gambar 1 adalah transkripsi andung di daerah Harian Boho Samosir, di lantunkan oleh seorang anak perempuan si Jenazah.

Dalam proses mentranskripsikan dari bunyi rekaman menjadi notasi memang dengan sengaja tidak disertakan tanda sukat dan garis birama. Keputusan ini diambil karena nyanyian andung sebagai kebiasaan adat meratapi anggota keluarga yang meninggal dilantunkan dengan cara yang spontan. Hal ini mengakibatkan tidak menentunya beat dimana frase akan dimulai. secara spontan dan lebih terdorong oleh perasaan maupun emosinya untuk menentukan kapan akan memulai frase berikutnya setelah frase yang sebelumnya selesai dilantunkan. Kondisi seperti ini mirip dengan cara pengaturan yang terdapat pada cara penulisan notasi komposisi-nonmetric duration.

Penulisan notasi tanpa tanda sukat adalah konsekuensi dari gaya komposisi yang tidak memiliki beat yang konstan, dimana hanya durasi suara dan diam yang ditentukan oleh nilai ketukan tiap-tiap nada. (Stone, Kurt, 1980: 94). Artinya, waktu kapan dimulainya antar masingmasing kesatuan unit nada (misalnya frase) bukan didasarkan pada beat yang sudah ditentukan, namun lebih mengalir bebas dan natural mengikuti cara pembagian jeda antar unit nada oleh yang memainkan musiknya. Demikian juga kecepatan durasi dalam memainkan antar unit-unit nada dalam komposisi nonmetric dimainkan dengan lebih mengalir atau bebas.
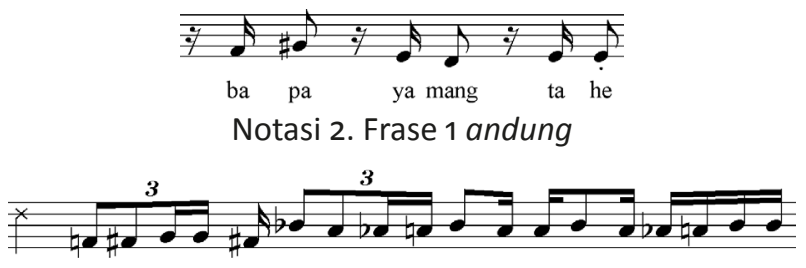

hu ma lo ja hu ho, o siap pu dan i H P mi di le an ho do Notasi 3. Frase 4 andung 
Andung ini memiliki kecederungan sulit untuk dikategorikan dalam pembagian struktur tertentu, dinyanyikan secara tunggal menyerupai orang berbicara, pergerakan melodinya terbatas, dan terdapat ornamen melantunkan huruf hidup dari suku kata di akhir frase. Penulisan notasi juga tidak menggunakan tanda sukat dan tanda birama karena nyanyian andung ini dilantunkan dengan cara yang spontan dan tidak menentunya pada beat yang mana masing-masing frase akan dimulai. Pengambilan nafas dilakukan dengan cepat sehingga menimbulkan efek bunyi tertentu di awal atau di akhir suatu frase pada nyanyian andung ini. Notasi 2 dan 3 adalah contoh frase dari andung yang menunjukan kecenderungan andung ini.

Pembahasan di atas adalah salah satu dari beberapa buah contoh Andung yang sudah ditulis menggunakan ilmu musik barat, meskipun terjadi beberapa pergeseran yang ada kaitannya dengan nada yang dihasilkan oleh andung yang dibawakan pada saat peristiwa kematian dengan andung yang sudah berupa kesenian

Budaya mangandung di masyarakat Batak Toba sudah berkembang menjadi sebuah kesenian yang berupa nyanyian, kesenian merupakan salah satu kebutuhan bagi masyarakat Batak Toba, dan andung merupakan salah satu kesenian yang berkaitan erat dengan upacara kematian. Andung sebuah kesenian yang berkembang dari upacara kematian, yang memiliki posisi yang sama dengan kesenian lainnya yang berasal dari Batak Toba.

Dalam semua kehidupan masyarakat Batak Toba, kesenian sudah melekat dan menjadi bahagian aktifitas kehidupannya. Berbagai bentuk kesenian tumbuh dan berkembang di tengah masyarakat Batak seperti nyanyian rohani, lagu ibadah, dan musik rohani serta musik ibadah di dalam kegiatan keagamaaan (agama kristen). Menggunakan perspektif Bourdieu, music merupakan habitus orang orang Batak (Prasetya, dkk, 2011). Menurut pakar musik Liturgi, Karl Edmund Prier, lagu ibadat diciptakan memang menjadi bagian integral dari ibadat sebagai sarana permohonan, puji syukur atau bagian iringan peribadatan. Karena keterikatannya itu syair lagu ibadat tidak bebas nilai (syair lebih penting dari unsur lagunya sendiri). Syair lagu Rohani dapat bersumber dapat dari pengalaman keagamaan, namun diciptakan untuk keperluan selain ibadat, seperti untuk hiburan pementasan, pertemuan dan lain-lain. Karena tidak ada tuntutan peribadatan, lagu rohani dapat juga berupa ungkapan subjektif perorangan (Bayu Wijayanto, 2016: 86).

Salah satu nyanyian dalam kehidupan masyarakat Batak yang merupakan ungkapan perseorangan adalah andung yang dapat dilihat pada adat upacara kematian, syair dalam nyanyian andung merupakan ungkapan perasaan kesedihan dari anggota keluarga yang lebih bersifat ratapan sebagai salah satu sarana pemenuhan kebutuhan sebagai ungkapan perasaan terhadap anggota keluarga yang meninggal. Berbeda dengan nyanyian rohani maka nyanyian andung tidak terikat nilai tetapi aspek teks syair sangat berhubungan dengan si individu yang meninggal, mengungkapkan perasaan anggota keluarga yang ditinggalkan dalam konteks upacara adat kematian, dalam hal ini syair berisikan ungkapan kebaikan si jenazah dimasa hidupnya. Meskipun dalam upacara adat kematian juga ditemui nyanyian kerohanian sebagai bagian dari ibadah untuk mendoakan si jenazah, tetapi nyanyian rohani dan nyanyian andung merupakan dua bentuk macam kesenian yang dapat ditemui di tengah masyarakat Batak Toba yang beragama kristen, secara perinsip sangat berbeda teks dan konteksnya. Nyanyian rohani untuk konteks individu yang masih hidup sebagai pemenuhan kebutuhan spiritualnya, andung untuk memenuhi kebutuhan keluarga yang di tinggalkan teraplikasi ke dalam bentuk ratapan di mana syairnya bersifat tentatif. Andung merupakan bagian dari ritual kematian dan nyanyian yang lain seperti nyanyian rohani merupakan bagian dari ritual kepercayaan yang ada hubungannya dengan ritual beribadah. Kedua nyanyian di atas merupakan bentuk aktualisasi masyarakat Toba dalam berkesenian.

\section{Penutup}

Masyarakat Batak Toba melihat kematian dengan cara yang unik, teraplikasi pada upacara atau ritual yang dilakukan ketika ada anggota keluarga yang meninggal. Konteks kematian dalam masyarakat Batak Toba adalah adat istiadat mereka. 
Berawal dari upacara adat kematian ini berkembang sebuah nyanyian yang menjadi ciri dari salah satu nyanyian khas masyarakat Batak Toba, yang dikenal dengan Andung yang dinyanyikan pada peristiwa kematian sebagai wujud kepedulian dan rasa sayang atau simpati dari keluarga yang ditinggalkan terhadap sijenazah. Kemampuan dalam melantunkan Andung tidak diajarkan atau diwarisi secara turun temurun, tetapi terbentuk karena kondisi budaya masyarakat Batak Toba, terdapat dalam upacara kematian, yang melakukannya tidak terikat pada usia tapi dibentuk oleh peristiwa kematian yang terjadi disebuah keluarga. Kemampuan mangandung tidak bisa dipelajari tetapi mengalir begitu saja jika ada anggota keluarga yang harus diratapi, dimana melalui syair diungkapkan tentang kehidupan si jenazah semasa hidupnya.

Andung saat ini sudah menjadi salah satu kesenian yang ditampilkan di tengah masyarakatnya, terlepas atau tidak dari ritual kematian yang terjadi. Secara spesifik masyarakat Batak Toba memiliki budaya mengandung sebagai salah satu dari keberagaman budaya yang tersebar di seluruh wilayah Batak Toba, juga sebagai salah satu penciri dari budaya masyarakat secara spesifik yang membedakannya dengan budaya dari daerah lain. Perkembangan masyarakat pendukungnya merubah beberapa unsur yang terdapat dalam andung, sehingga menjadikannya nyanyian yang bersifat lebih tentatif.

\section{Kepustakaan}

Nainggolan, Togar. 2012. Batak Toba: Sejarah dan transformasi religi. Medan: Bina Media Perintis.

Kurt. 1980. Stone Music Nation in the Twentieth Century. London \& New York: W. W. Norton \& Company

Mack Dieter. 1986. Ilmu Melodi. Yogyakarta: Pusat Musik Liturgi.

Nettl, Bruno. 1964. Theory and Method in Ethnomusicology. New York: The Free Press.

Prasetya, HB; Timbul Haryono; Lono L. Somatupang. 2011. Habitus, Ngeng, dan Estetika Bunyi Mleset dan Nggandhul pada Karawitan. Paradigma Jurnal Kajian Budaya.
Vol. 1 No. 2.

Siahaan, Nalom.1982. Adat Dalihan Na Tolu:

Prinsip dan Pelaksanaannya. Jakarta: Tulus Jaya.

Sibarani. R. 2012 Kearipan Lokal Hakekat, Pera, dan Metode Tradisi Lisan. Jakarta: Assosiasi Tradisi Lisan (ALT).

Sihombing, T.M. 1986. Filsafat Batak: Tentang Kebiasaan-kebiasaan Adat Istiadat. Jakarta: Balai Pustaka.

Sinaga, Richard. 2010. Meninggal Adat Dalihan $\mathrm{Na}$ Tolu. Jakarta: Penerbit Dian Utama.

SJ., Prier, Karl-Edmund. 1966. Imu bentuk Musik. Yogyakarta: Pusat Musik Liturgi.

Stone, Kurt. 1980. Music Nation in the Twentieth Century, London \& New York: W. W. Norton \& Company.

\section{Disertasi}

Hodges, William Robert Jr. 2009. "Ganti Andung Gabe Ende (ReplacingLament, Becoming Hymns): The Changing Voice of Grief in the Pre- funeral Wakes of Protestant Toba Batak (North Sumatra, Indonesia)", [Disertasi] University of California Santa Barbara

Sinaga, Mei Sonni. 2010. Makna simbolik gondang Mula Jadi Na bolon Dalam Upacara Pameleon Bolon Masyarakat parmalim Di Hutatinggi, Kecamatan Lagu Boti, Kabupaten Toba Samosir Propinsi Sumatera Utara. [Tesis]. Program Seni Pertunjukan dan seni Rupa Sekolah Pasca Sarjana Universitas Gadjah Mada Yogyakarta.

Wijayanto Bayu, Lono L. Simatupang, dan Victor Ganap. 2016. Musik Gospel, Sebagai Ekspresi Spiritual-Musik Jemaat Gereja Kristen Kharismatik. Journal of Urban Society's Art. Volume 3 No. 2- Oktober 2016.

\section{Pustaka Laman}

Hodges, William Robert Jr. 2006. “Tudia ho, dung mate ho?: Manifestasi dan Mediasi Disonasi Kognitif dalam Konteks Lagu-lagu Ratapan di Kalangan Kristen Protestan Batak Toba. Etnomusikologi. Vol. 2 No.1, Mei 2006.", 
Diunduh dari http://www.etnomusikologiusu. com/uploads/1/8/0/0/1800340/ rhodgestudiaho.pdf

\section{Narasumber}

Manna Sitinjak 88 tahun, wirasuasta, pelantun nyanyian andung Baniara Samosirara, wawancara dilakukan pada15 Juli 2016, 21 Juli 2016.

Marisi Lumban Gaol 78 tahun, wiwasuasta, pelantun nyanyian andung, Desa Lumban Sinaga Dolok Sanggul, wawancara dilakukan pada 13 April 14, 17 -18 Juli 2016, 20 September, 2016, 78

Rumona Lumban Gaol 53 tahun, wirasuasta, pelantun nyanyian andung, Desa Lumban Sinaga Doloksanggul 16-17 September 2016.

Tianggur Lumban Gaol 75 tahun, wirasuasta , pelantun nyanyian andung Desa Lumban Sinaga Dolok Sanggul, wawancara dilakukan pada 13 April 2016, dan 27 Juli 2016, 2016. 